\title{
A Case Study on the Construction of a CLT Building Without a Preliminary Roof
}

\section{Eneli Liisma*}

AS Merko Ehitus. Järvevana tee 9g, Tallinn 11314, Estonia

Tallinn University of Technology, Department of Civil Engineering and Architecture. Ehitajate tee 5, Tallinn 19086, Estonia

\section{Babette Liseth Kuus}

AS Merko Ehitus. Järvevana tee 9g, Tallinn 11314, Estonia

\section{Villu Kukk, Targo Kalamees}

Tallinn University of Technology, Department of Civil Engineering and Architecture. Ehitajate tee 5, Tallinn 19086, Estonia

*Corresponding author: eneli.liisma@merko.ee

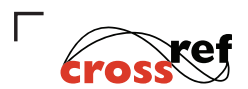

http://dx.doi.org/10.5755/j01.sace.25.2.22263

This paper focuses on cross-laminated timber (CLT) and how it is affected by the dynamic properties of moisture during installation in the cold and humid climate of Estonia. The moisture safety principles are designed using a case study of comparable activities with 4-D principles and on-site water content monitoring. On-site water content monitoring was done on the CLT elements that were installed and a parallel polygon specimen. Polygon testing was arranged with reduced size CLT elements subject to different conditions, with some exposed to the climate, some protected from precipitation, and some covered with film.

The moisture content $(\mathrm{MC})$ of the uncovered horizontal CLT element that was exposed to the climate reached over $25 \%$ after higher precipitation and the MC after prolonged direct exposure can reach up to $40 \%$ in a week, giving a clear signal of high risk areas for moisture safety. Installing a partly weather protected CLT element without a preliminary roof is a high-risk arrangement, but is essentially possible in a cold and humid climate. Moisture safety planning and a lean strategy must be applied with timber construction.

Keywords: CLT; moisture safety; construction quality; building technology; moisture content.

The building and construction industry is facing a significant challenge in reducing its carbon emissions (Lai et al., 2017). Greater use of wood-based materials helps to reduce the use of fossil-fuel energy and to mitigate climate change. Dodoo et al., (2010) show that the low-energy version of the cross laminated timber (CLT) building gives the lowest lifecycle carbon emissions while the conventional version of the beam-and-column building gives the highest lifecycle emissions. CLT-element design has been growing noticeably for the past decade in all leading European countries and in Central Europe in particular (Brandner et al., 2016; Hurmekoski et al., 2015; Schickhofer et al., 2017).

\section{Introduction}

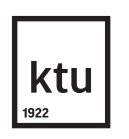

Journal of Sustainable Architecture and Civil Engineering Vol. 2 / No. 25 / 2019 pp. 53-62 DOI 10.5755/j01.sace.25.2.22263 
Although the mechanical properties of CLT are equivalent in scale to those of several other main construction materials, using timber poses the severe issue of moisture safety (Öberg and Wiege, 2018) as moisture is the most important factor affecting the durability of wood and damage to it. Optimum moisture conditions for most decay fungi mean moisture content (MC) above fibre saturation, which is usually around 25-30\% (Carll and Highley, 1999), and the upper safe limit for MC for CLT structures is considered to be $15-17 \%$ by mass depending on the vapour permeability of the covering material (Kukk et al., 2019; Lepage et al., 2017). If the moisture that is built in from exposure to weather conditions cannot be dried out from timber construction during the installation process, moisture safety can be considered to be compromised. Excess moisture means there is a critical issue in achieving moisture safety of wooden construction and shortens the service life of the building (Brischke et al., 2006; Kalamees, 2002).

The construction industry by its nature has many particular problems and requirements (Ofori, 2000). New technologies are resisted because they require changes to be made to processes that can entail risks and unforeseen costs (Häkkinen and Belloni, 2011). Testing and evaluating new structures, technologies and construction processes in pilot projects helps to minimise risks before market launch. Moisture management has been cited as a difficult and expensive process that arises when building with wood frame structures (Globe Advisors, 2016). As fully moisture safe CLT construction technology is still relatively new in many countries, it also demands further research and development.

Three main options have been developed for weather protection during building, and these are scaffolding cover, stationary or movable roof cover, and climbable cover. Temporary tents have been used in Europe to protect entire project sites and provide good protection from rain, snow or wind (Constance Thivierge, 2011). In practice the temporary tents that can prevent rainwater damage or other weather protection solutions are not always used. This may be because the builder has inadequate experience of the moisture-safe construction principles, lacks knowledge of mould problems, or has previous experience with concrete structures that tolerate moisture a little better. If the temporary tent is omitted during the bidding stage, it is difficult to find the finances and time to add it to the construction budget and calendar later on.

This study analyses the options and risks for constructing a CLT-building without temporary movable tents covering the project site. The Viimsi State Gymnasium school building in Estonia was selected as a pilot project.

\section{Methods}

\section{The case study building}

The case study building, Viimsi State Gymnasium school in Estonia, is one of the first public multi-storey buildings to be built mainly of CLT (Cross Laminated Timber). The design was produced by Novarc Group AS and KAMP Arhitektid OÜ in 2017, and the building was constructed by Merko Ehitus Eesti AS in 2018. The floor area was $4300 \mathrm{~m}^{2}$ and construction cost was 6.1 million euros. CLT elements were used for the vertical and horizontal structure, Fig. 1.
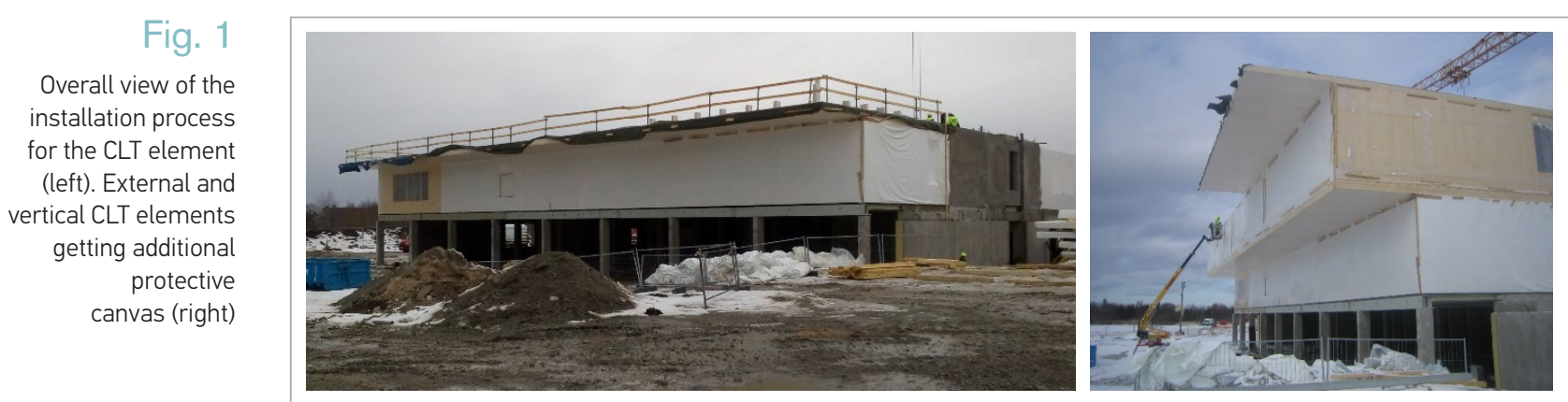
In this case study no temporary tent or preliminary roof for weather protection was set up during the installation process and so considerably greater risk was taken because there was no proper moisture safety plan in the bidding stage of the project. The CLT elements were protected only by packaging PE foil and were sealed during the production process to ensure the MC of $13 \% \pm 2 \%$ declared by the factory, Peetri Puit OÜ.

\section{Moisture safety management principles}

The set up for this case study was to predict and map out the most critical positions of the CLT elements that were exposed to weather conditions during the installation process with minimal precautionary measurements for moisture safety. Preliminary on-site activities followed the "4D principles" of FPlnnovations (Wang, 2016) - deflection, drainage, drying, and durable material, see Fig. 2.

All the vertical elements were sealed and moisture safe, but all the horizontal elements were unsealed before installation and subsequently covered. Accordingly the most critical positions are all the horizontal elements and the horizontal-vertical unit perimeter elements.

On-site moisture safety was divided into full-scale monitoring of CLT elements for their actual moisture status and monitoring of reduced size CLT element polygons, which were compared with the building construction. Additionally, laboratory measurements for capillary absorption were taken to understand the effect of water migration.

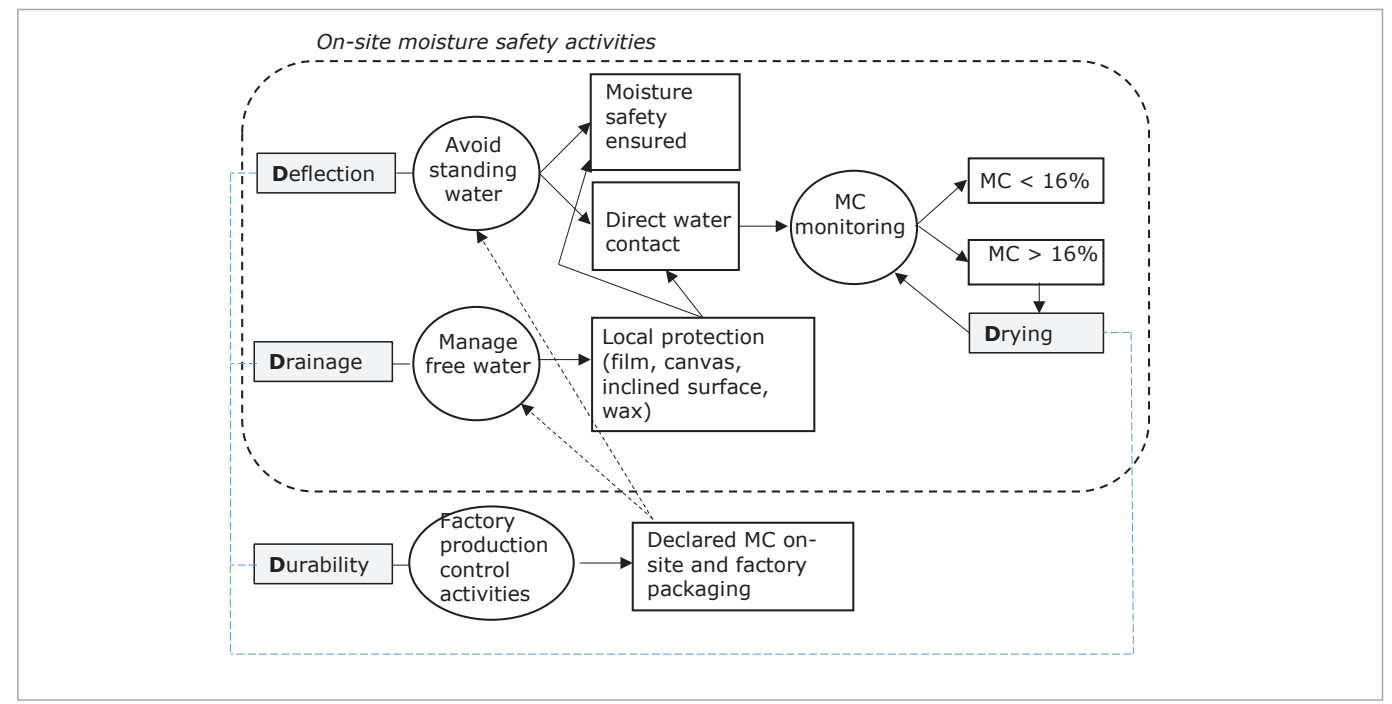

Wall elements were transported in packaging PE-foil and were kept in it during storage on site and after installation. The covering film for the floor element was removed before installation because it was joint specific, Fig. 3.

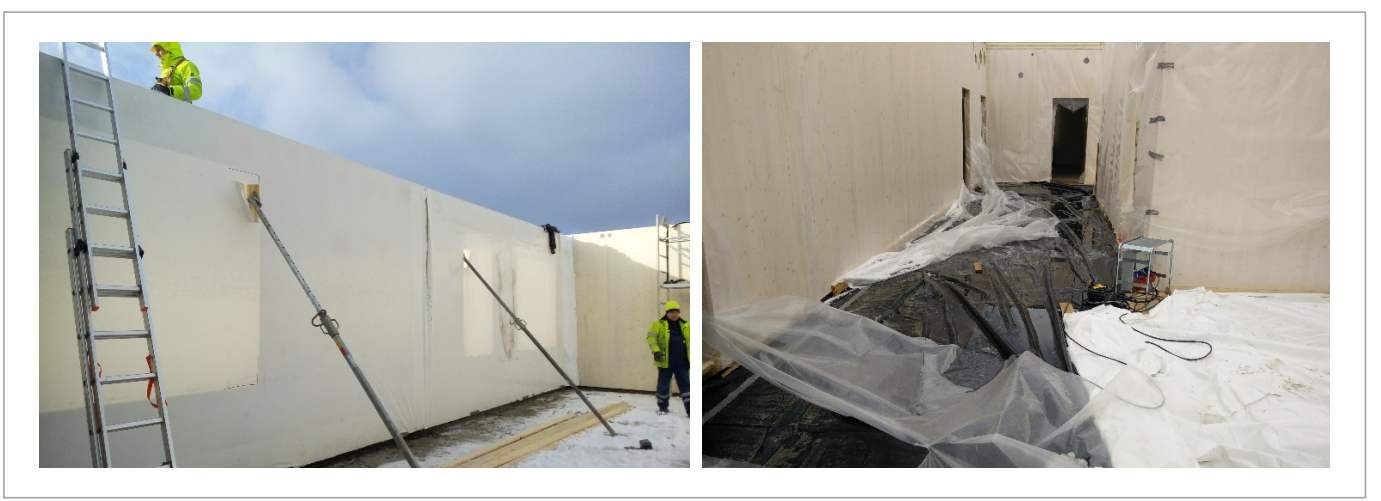

Fig. 3

CLT elements covered by PE foil before, during and after installation 


\section{Moisture measurement}

After installation of the CLT-elements, the water content was monitored using a pin electrode moisture meter (Extech M0290) with short pins of $10 \mathrm{~mm}$ for external layers and long pins of $80 \mathrm{~mm}$ to get internal results. The measuring was done during installation and the measuring points selected were the most critical positions for moisture, as discussed previously, Fig. 4.

Fig. 4

Sample of the high moisture risk position
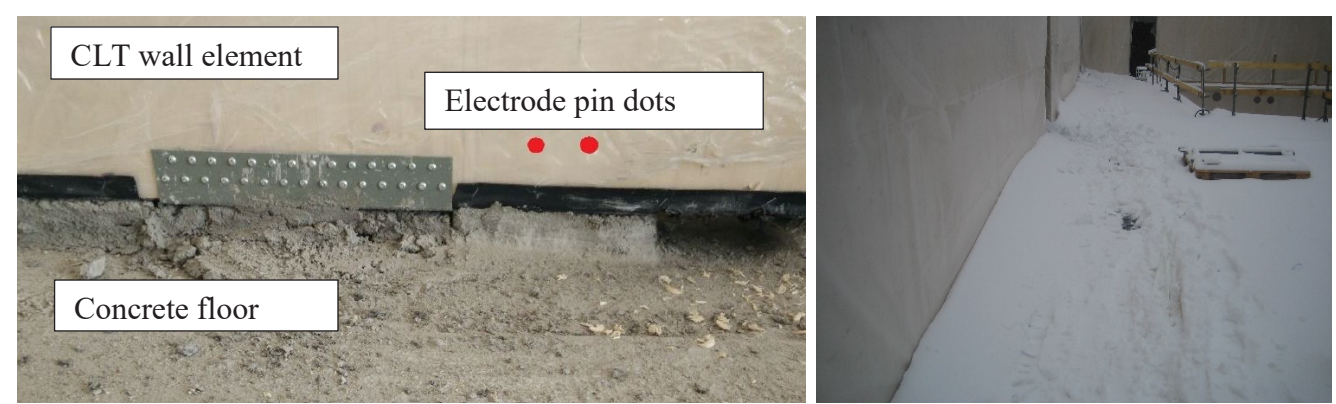

The joint between the CLT wall element and the concrete floor with moisture meter electrode dots (left). A very extreme situation with heavy snowfall on the floor elements and near the CLT wall element, however snow was instantly removed after precipitation (right)

\section{Monitoring of moisture safety with a reduced size CLT element}

Parallel polygon testing with reduced size vertical and horizontal CLT elements $(300 \times 1000 \times 60 \mathrm{~mm})$ was done near to the building site to compare the MC of unsealed and covered CLT elements with the unsealed and uncovered elements in the real life building, Fig. 5. Three constant situations were set up to provide different moisture conditions, with elements unsealed and exposed to all weather conditions, elements unsealed but under protective cover, and elements sealed in the factory and kept unopened.
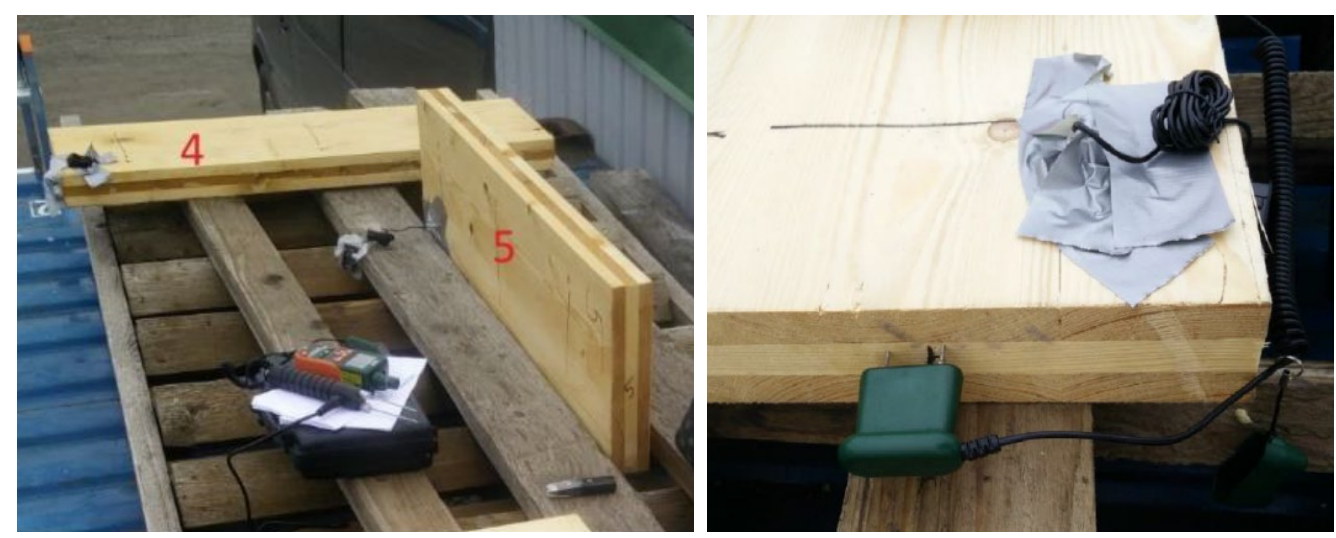

Capillary water absorption was measured in laboratory conditions $\left(20 \pm 2^{\circ} \mathrm{C}\right.$ and $\left.\mathrm{RH} 50 \pm 5 \%\right)$. Both vertical and horizontal element water exposure was imitated as seen in Fig. 6. 


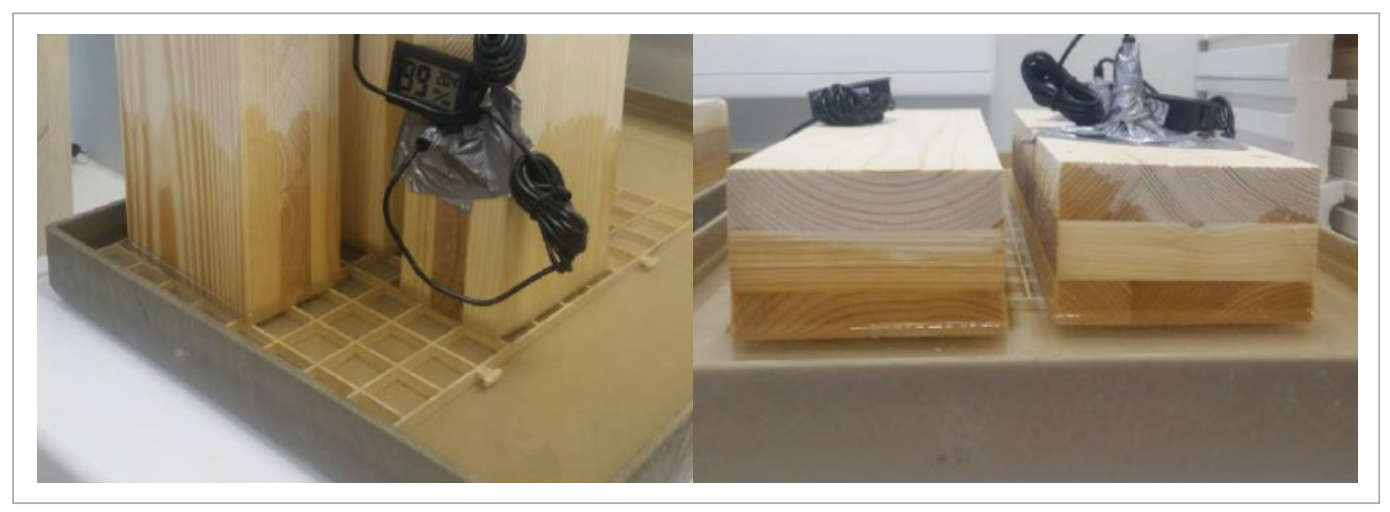

\section{Fig. 6}

Capillary absorption imitation of vertical CLT element (left). Capillary absorption of the horizontal CLT element (right)

\section{Construction process}

The CLT installation period was eight weeks (20.02.2018 - 13.04.2018) and the installation of the $\mathrm{CLT}$ elements was done during a period of relatively high precipitation. The total rain load was over $90 \mathrm{~mm}$, with individual higher results in one week above $30 \mathrm{~mm}$. Fig. 7 shows the progress of the installation of the CLT elements and the rain intensity during this period. The horizontal elements were moderately exposed to standing water and infrequent snowfalls, both removed within a maximum of 15 hours as one of the principles of 4-D. It must be stated that snowfall precipitation wasn't measured separately during the construction process due to deflection and drainage activities. Otherwise every $1 \mathrm{~m} 3$ of snowfall would add approximately $250 \mathrm{~kg}$ extra water risk for timber elements. The pre-planned 4-D moisture safety principles (Fig. 2) were an innovation for construction company and were mostly followed.

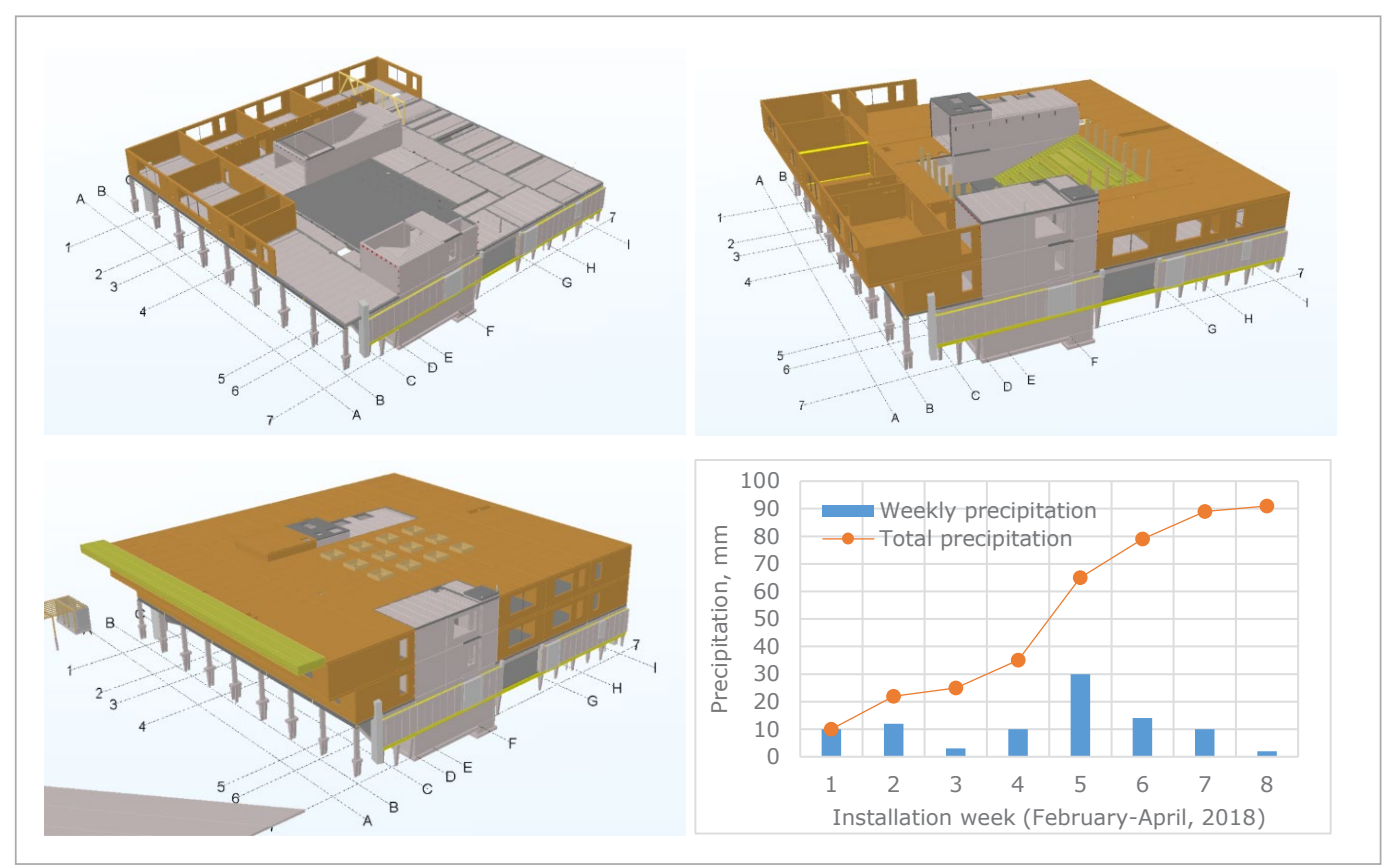

Fig. 7

Installed CLT elements: after one week (top left), after five weeks (top right), and after eight weeks (bottom left). Precipitation during the installation period (bottom right) 
Site visits indicated that even when the horizontal surfaces were covered with preliminary foil, microbial growth was not prevented and in extreme cases the growth could be seen with the naked eye.

Fig. 8

Water (left) and microbial growth (right) on the CLT

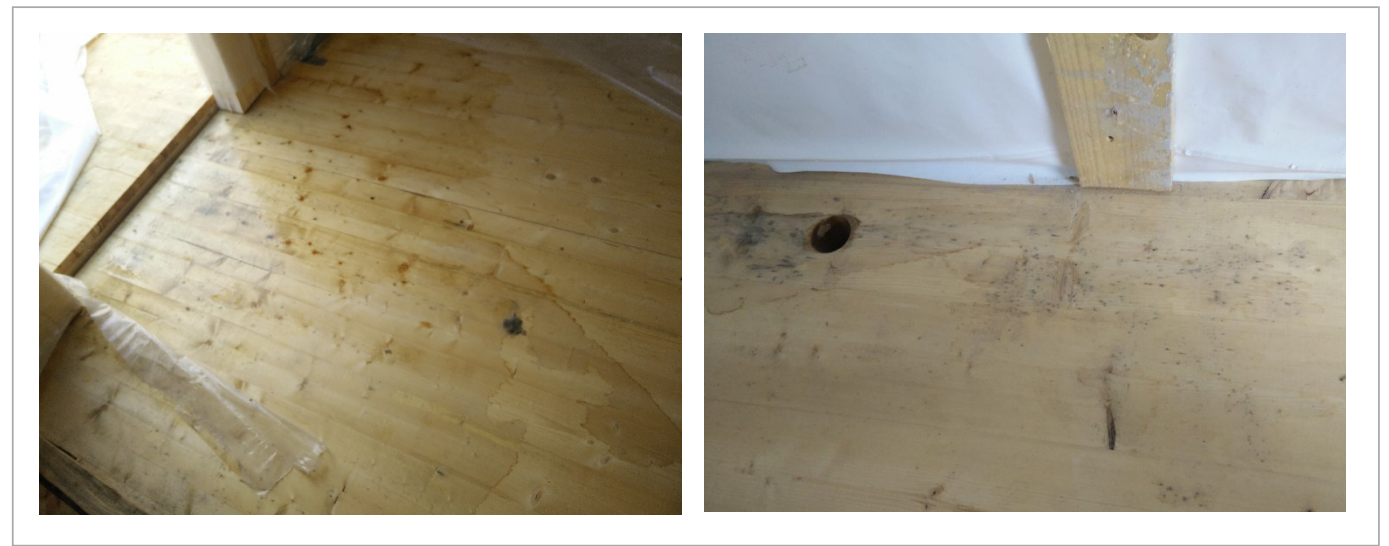

\section{Moisture content in CLT elements exposed to precipitation}

The manufacturer declared the MC of the CLT was $13 \% \pm 2 \%$. In this case the study elements transported to the site had an initial water content of up to $13 \%$, and mostly around $10 \%$ by mass. The MC of the CLT elements reached up to $15 \%$ by mass at the end of the installation process. Nevertheless a decreasing dynamic was apparent in time due to the sorption process, Fig. 9.

It was noted that the short pin electrodes $(10 \mathrm{~mm})$ clearly found higher moisture content in the horizontal elements than in the horizontal-vertical joints. However, the long pin electrodes $(80$ $\mathrm{mm}$ ) indicated irregular moisture content results. If extremums are excluded, the average results are equivalent whatever the direction of the CLT element. This points to internal moisture safety for the CLT elements. However, precipitation type (rain/snow) wasn't measured separately, it can be stated that rain has higher effect on $\mathrm{MC}$ compared to snow that was constantly removed from horizontal surfaces. But without deflection and drainage activities, snowfall would have considerable risk on the $\mathrm{MC}$ increase in CLT elements when melted as described above.

Fig. 9

The moisture content dynamics of the

CLT elements after precipitation in the final phase of installation

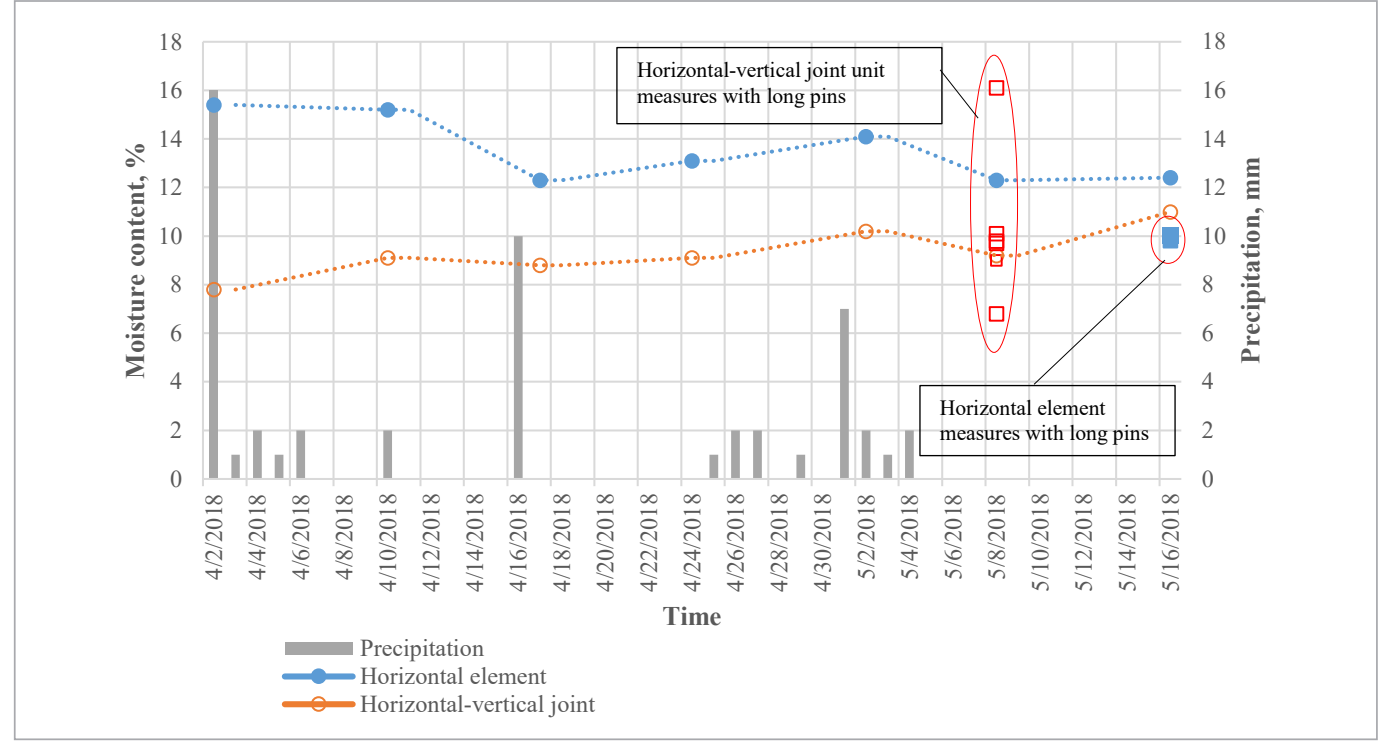




\section{Polygon testing moisture content in the CLT elements}

Fig. 10 shows that after higher precipitation the uncovered and exposed horizontal CLT elements reached a moisture content of over $25 \%$ that lasted several weeks before falling below the $17 \%$ limit with the short pins that measure the external layer. The longer pins measuring internal moisture showed water content was below $25 \%$ after the precipitation but it took a month to dry out to $17 \%$. For the CLT elements that were covered with no direct water contact, the MC remained under the upper safe limit of $17 \%$ both internally and externally.

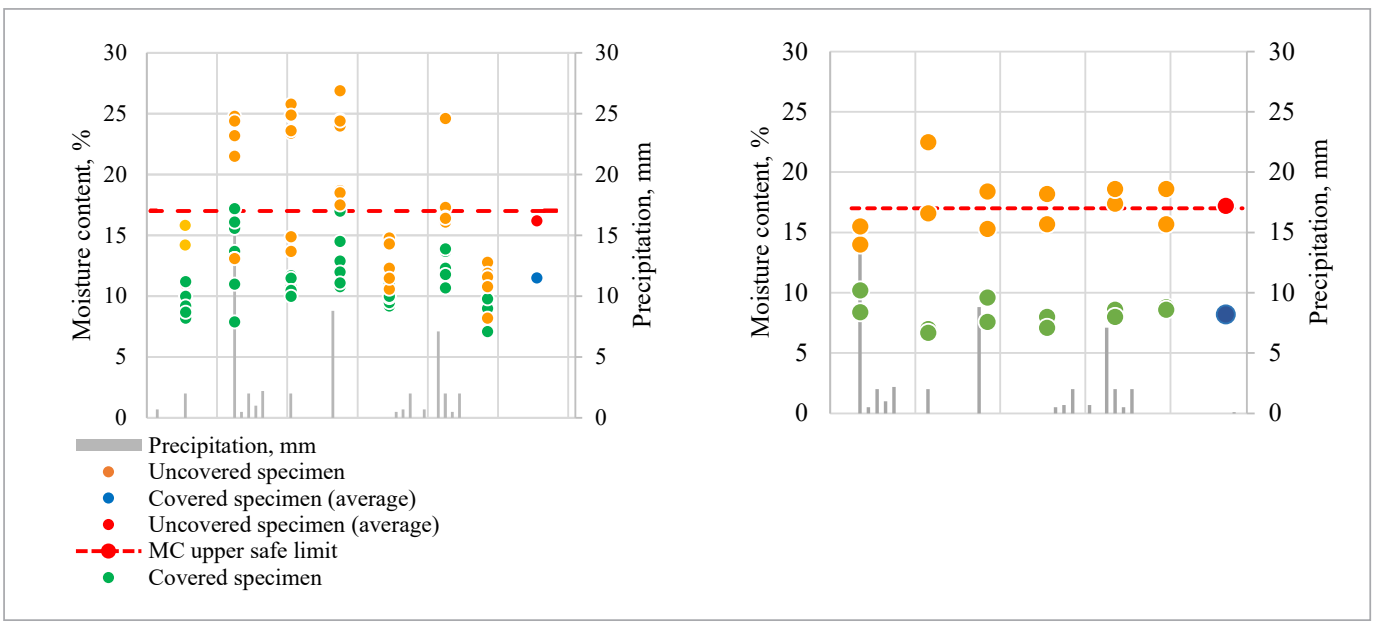

Fig. 10

MC monitoring of the horizontal CLT elements in polygon testing: external MC with short pins (left); internal MC with long pins (right)

Fig. 11 shows that the behaviour of the wall elements was similar but the MC was approximately 10 percentage points lower. The MC of the wall elements exceeded the upper safe limit and did not dry out during the final month of installation. The difference in the internal and surface moisture levels shows the importance of the measurement depth for the water content of the CLT elements. The key factor that must be pointed out for the horizontal-vertical joint performance is that the bottom end of the vertical element must be sealed with rubber or another waterproof layer to block capillary water migration, as seen previously in Fig. 6 .

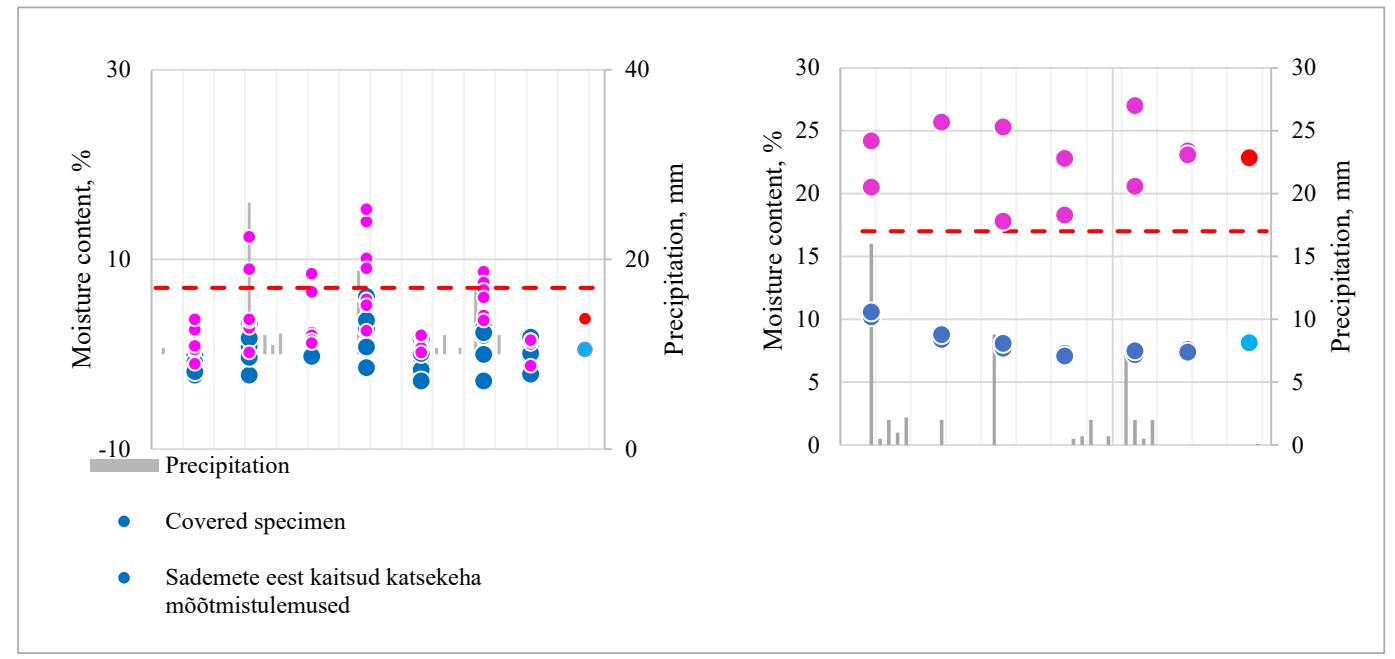

Fig. 11

$\mathrm{MC}$ monitoring of the vertical CLT elements in polygon testing: external MC with short pins (left); internal MC with long pins (right)

The capillary absorption results from the laboratory tests of the CLT elements show that prolonged direct water contact can lead to MC of up to $40 \%$ by mass in a week, which is a clear indicator of 


\section{Discussion}

Conclusions high risk areas in the context of moisture safety. For future work, it would be relevant to examine water migration and its behaviour in the CLT structure subject to the orientation of the timber fibre.

The current study showed that installing partly weather protected CLT elements without a preliminary roof is a high-risk arrangement in a cold-humid climate. The shortcomings in the construction technology, such as the lack of rain protection for the CLT and the absence of any moisture safety protocol during the construction period may lead to high humidity conditions for long periods in the externally insulated CLT panels, raising concern about condensation and the risk of mould developing (Kalamees et al., 2014). Therefore, moisture safety should be included as part of the design and manufacturing process and also the construction process. The ByggaF method is a good example of this (Mjörnell et al., 2011).

Öberg and Wiege, (2018) showed that a roof cover is required if the expected rain load is above $40 \mathrm{~mm}$ or the building time is over two weeks. In this case study the horizontal elements were moderately exposed to standing water but it was removed within a maximum of 15 hours as one of the principles of 4-D.

Although the current study showed that a preliminary tent should be required for construction with CLT when the aim is to construct a moisture safe building, CLT buildings have been successfully put up in Norway and Sweden without weather protection. However, it must be noted, that standing water was strictly prevented. In contrast, a serious moisture failure was reported from the Jätkäsaari district in Finland, where a new rental housing block district has fallen prey to water damage just one month after the occupants moved in (Bäckgren, 2017; YLE, 2017).

Polygon testing showed that uncovered and exposed horizontal CLT elements reached a moisture content of over $25 \%$ after higher precipitation. After exposure to prolonged direct water contact, the $\mathrm{MC}$ can reach up to $40 \%$ in a week. These results clearly support the use of temporary rain protection during the construction of wooden buildings.

When the CLT was protected during construction with preliminary PE-foils and 4-D moisture safety principles were implemented, the MC of the CLT was lower. If direct water contact was immediately eliminated from the CLT elements, the regions with the highest moisture risk are horizontal floor elements and floor-wall joints. Critical on-site positions did not exceed the upper safe limit of $\mathrm{MC}$ of $17 \%$ in the CLT elements with vapour permeable insulation, nor did the moisture migrate to the internal timber structure.

This case study showed that without protection from a preliminary roof or temporary tent, installing CLT elements without persistent moisture damage appearing is very risky, but still essentially possible. A factor that makes a considerable difference is the critical uncovered area limit. This case study finds that a locally protected area of up to $1350 \mathrm{~m}^{2}$ and approximately 90 $\mathrm{mm}$ of precipitation within the installation period are manageable parameters. However, it must be strictly understood that moisture safety pre-planning and a lean strategy must be applied with timber construction.

\section{Acknowledgement}

We thank the Merko Ehitus Eesti AS site team for their cooperation and for helping with on-site activities and Peetri Puit OÜ for organising the CLT polygon specimen. This research was supported by the Estonian Research Council with Personal research funding PRG483 “Moisture safety of 
interior insulation, constructional moisture and thermally efficient building envelope", Institutional research funding grant IUT1-15, Estonian Centre of Excellence in Zero Energy and Resource Efficient Smart Buildings and Districts, ZEBE, grant TK146 funded by the European Regional Development Fund.

Bäckgren, N., 2017. Jätkäsaaren homehtuneet Wood City - puukerrostalot ovat Stora Enson osin rahoittama tutkimuskohde - Työmaalla testattiin, miten puurakentaminen onnistuu ilman sääsuojaa. Rakennuslehti.

Brandner, R., Flatscher, G., Ringhofer, A., Schickhofer, G., Thiel, A., 2016. Cross laminated timber (CLT): overview and development. European Journal of Wood and Wood Products 74, 331-351. https:// doi.org/10.1007/s00107-015-0999-5

Brischke, C., Bayerbach, R., Otto Rapp, A., 2006. Decay-influencing factors: A basis for service life prediction of wood and wood-based products. Wood Material Science and Engineering 1, 91-107. https:// doi.org/10.1080/17480270601019658

Carll, C.G., Highley, T.L., 1999. Decay of wood and wood-based products above ground in buildings. Journal of testing and evaluation. Vol. 27, no. 2 (Mar. 1999).:p. 150-158. 27, 150-158. https://doi. org/10.1520/JTE12054J

Constance Thivierge, 2011. Building with CLT panels durability considerations. Wood design \& building 38-41.

Dodoo, A., Gustavsson, L., Sathre, R., 2010. Life cycle primary energy implication of retrofitting a wood-framed apartment building to passive house standard. Resources, Conservation and Recycling 54, 1152-1160. https://doi.org/10.1016/j.resconrec.2010.03.010

Globe Advisors, 2016. Study of Insurance Costs for Mid-Rise Wood Frame and Concrete Residential Buildings.

Häkkinen, T., Belloni, K., 2011. Barriers and drivers for sustainable building. Building Research \& Information 39, 239-255. https://doi.org/10.1080/09613 218.2011.561948

Hurmekoski, E., Jonsson, R., Nord, T., 2015. Context, drivers, and future potential for wood-frame multi-story construction in Europe. Technological Forecasting and Social Change 99, 181-196. https:// doi.org/10.1016/j.techfore.2015.07.002

Kalamees, T., 2002. Failure analysis of 10 year used wooden building. Engineering Failure Anal- ysis 9, 635-643. https://doi.org/10.1016/S13506307(02)00025-0

Kalamees, T., Paap, L., Kuusk, K., Mauring, T., Hallik, J., Valge, M., Kalbe, K., Tkaczyk, A.H., 2014. The first year's results from the first passive house in Estonia, in: Arfvidsson, J., Harderup, L.-E., Kumlin, A., Rosencrantz, B. (Eds.), Proceedings of 10th Nordic Symposium on Building Physics. 15-19 June 2014 Lund, Sweden, pp. 758-765.

Kukk, V., Külaots, A., Kers, J., Kalamees, T., 2019. Influence of interior layer properties to moisture dry-out of CLT walls. Canadian Journal of Civil Engineering cjce-2018-0591. https://doi.org/10.1139/ cjce-2018-0591

Lai, X., Liu, J., Shi, Q., Georgiev, G., Wu, G., 2017. Driving forces for low carbon technology innovation in the building industry: A critical review. Renewable and Sustainable Energy Reviews 74, 299-315. https://doi.org/10.1016/j.rser.2017.02.044

Lepage, R., Eng, P., Higgins, J., Finch, G., 2017. Moisture Uptake Testing for CLT Floor Panels in a Tall Wood Building in Vancouve, in: Conference: 15th Canadian Conference on Building Science and Technology, At Vancouver, BC. Vancouver, B.C., Canada, p. 17.

Mjörnell, K., Arfvidsson, J., Sikander, E., 2011. A Method for Including Moisture Safety in the Building Process. Indoor and Built Environment 21, 583-594. https://doi.org/10.1177/1420326X11428340

Öberg, J., Wiege, E., 2018. Moisture risks with CLT-panels subjected to outdoor climate during construction-focus on mould and wetting processes Fuktrisker på KL-trä som utsätts för yttre klimat under produktion-fokus på mögel och uppfuktning. KTH Royal Institute of Technology, Stockholm.

Ofori, G., 2000. Challenges of Construction Industries in Developing Countries: Lessons from Various Countries, in: 2nd International Conference on Construction in Developing Countries: Challenges Facing the Construction Industry in Developing Countries. 15-17 November 2000, Gabarone, pp. 1-13. 
Schickhofer, G., Flatscher, G., Ganster, K., Sieder, R., Zimmer, S., 2017. A Status Report from the CLT Hot Spot in Europe | Austria, in: CLT Seminar Sola City Conference Center, Tokyo.
Wang, J., 2016. Guide for On-site Moisture Management of Wood Construction.

YLE, 2017. More water damage detected at new housing blocks in Helsinki.

\section{About the Authors \\ ENELI \\ LIISMA}

Head of quality management

department

AS Merko Ehitus Eesti

Main research area

Quality control, building materials

\section{Address}

Järvevana tee 9g, Tallinn 11314, Estonia. Tel. +372 805105

\section{BABETTE LISETH KUUS}

Site technician AS Merko Ehitus Eesti

\section{Main research area}

Quality control, building materials

\section{Address}

Järvevana tee $9 \mathrm{~g}$, Tallinn 11314, Estonia Tel. +372 805105 E-mail: babetteliseth kuus@merko.ee
VILLU

KUKK

PhD candidate

Tallinn University of Technology, Department of Civil Engineering and Architecture, Nearly Zero Energy Building Research Group

Main research area

Hygrothermal behaviour of CLT structures

\section{Address}

Ehitajate tee 5, Tallinn 19086, Estonia Tel. +3726202403

E-mail: targo. kalamees@taltech.ee
TARGO

KALAMEES

Professor of Building Physics

Tallinn University of Technology, Department of Civil Engineering and Architecture, Nearly Zero Energy Building Research Group

Main research area

Building envelope structures; renovation of buildings; hygrothermal behaviour of buildings structures (computer simulations, laboratory experiments, field studies); moisture safety of buildings; boundary conditions for hygrothermal simulations and experiments; building energy consumption and healthy building design; indoor climate and indoor air quality of residential-, office-, and historic buildings.

\section{Address}

Ehitajate tee 5, Tallinn 19086, Estonia Tel. +3726202403 E-mail: targo. kalamees@taltech.ee 